\title{
The Influence of Accessibility, Personal Sales and Interest in the Decision of Use of Micro Business Credits (KUM) and Customer Loyalty (Study on Customer of BANK MANDIRI Sepanjang Kota Sidoarjo)
}

\author{
Sonny Brilliant Candra Negara \\ Narotama University, Surabaya \\ sonny.brilliant@gmail.com
}

\begin{abstract}
This study aims to determine the effect of accessibility, personal selling, interest rates on micro business credit usage decisions and customer loyalty in independent banks throughout the city of Sidoarjo.Methodology: This type of research is quantitative. The research data are primary data obtained from samples with the number of 100 respondents who are customers of Bank Mandiri throughout the city of Sidoarjo. The sampling technique is done using a questionnaire. The data analysis used is Partial Least Square (PLS). Data is processed using SmartPLS.The results of the study show that accessibility, personal sales, and interest rates are significantly influenced by purchasing decisions and customer loyalty. Given accessibility, personal sales and interest rates that have a significant positive influence and a major contribution to Bank Mandiri's buying and loyalty decisions throughout the city of Sidoarjo. Directions must pay attention to accessibility, personal sales, and interest rates
\end{abstract}

Keywords: accessibility, personal sales, interest rates, purchasing decisions and loyalty.

\section{INTRODUCTION}

Customer loyalty is a customer's attitude in the form of commitment, and not all customers form loyalty to the bank for various reasons. In general, banking that is engaged in services must avoid the goal of no loyalty because it will experience difficulties in forming loyal customers and will weaken the bank itself, so that various marketing strategies are carried out to maintain these customers. One special feature of customer loyalty is that they make purchases regularly and repeatedly, even they voluntarily recommend the superiority of products or services they have at the bank. The process towards the loyalty level begins when the customer evaluates the product or service, service, and certain program offered by the bank, so that the customer has specific experience about his purchasing decision or credit decision. Another thing that is not less important is the situational factor of the customer's attitude also influence in making purchasing decisions or credit submission decisions so that it is easy to move to products or services that are competitors. The situational factor can be triggered by something outside the customer's self, such as: reference factors, word of mouth persuasion, program stimuli from the bank, etc. The results of empirical studies of customer loyalty are situations where consumers are positive towards the product or producer (service provider) and accompanied by a consistent repurchase pattern Tjiptono (2000).

The focus of this research is on a government banking service industry called MANDIRI BANK, throughout the city of Sidoarjo, located on Jl. Along Town House A-06 RT.019 RW.02 Sidoarjo. This

The Influence of Accessibility, Personal Sales and Interest in the Decision of Use of Micro Business Credits (KUM) and Customer Loyalty (Study on Customer of BANK MANDIRI Sepanjang Kota Sidoarjo)

Sonny Brilliant Candra Negara 
banking service has been established since 1998 and has more than 100 branches throughout Indonesia. This study aims to analyze the influence of accessibility, personal selling and interest rates on the decisions of micro-business credit applications and customer loyalty. For banking services, it is undeniable that accessibility is one of the factors in choosing the banking services that customers will visit. accessibility is a measure of convenience or ease of location of land use that interacts with one another Black (1981). Banking services are required to always keep abreast of the times in providing accessibility that is able to meet customer desires so that customers do not move elsewhere. In order to increase the number of visits or banking services business customers also provide interest rate promo programs that can compete, where the interest rate is the provision of low interest rates compared to other banks provided to customers. The interest rate program can be in the form of; low interest rates for microbusiness loans, namely low interest rates, are given to customers who take micro-business loans to encourage customers to take micro-credit (KUM) in a higher number or limit, so that customers are also satisfied when applying for micro-business loans.

\section{LITERATURE REVIEW}

\section{Accessibility}

Accessibility is a measure of comfort or ease of location of land use that interacts with one another Black, (1981). Direct communication of bank officers with prospective Micro Business Credit (KUM) customers, thus forming an understanding of Micro Business Credit (KUM) and so that customers are willing to use Micro Business Loans (KUM). There is also According to Baker (2002) accessibility may have different meanings from each customer, so this needs to be varied.

Hypothesis 1: Accessibility has a significant effect on the decision on the use of micro-business loans, the better the bank's accessibility, the higher the interest in using micro-business loans (KUM)

Meaning: the higher the accessibility offer provided by a banking, the higher the customer's interest in applying for micro-business credit (KUM)

Hypothesis 2: Accessibility has a significant effect on loyalty, the better the bank's accessibility, the higher customer loyalty

Meaning: the higher the accessibility provided by a banking system, the higher the customer loyalty

\section{Personal Selling}

Personal Selling is direct communication (face to face) between the seller and prospective customers to introduce a product to prospective customers and build understanding of the product so that they will then try to buy it according to Tjiptono (2000). The ability of bank officers to offer and educate a Micro Business Credit (KUM) loan to prospective customers who do not understand about Micro Business Credit (KUM) loans, so they are interested in using Micro Business Credit (KUM) in Bank Mandiri throughout the City. According to Saladin (2007) states that personal selling is an oral presentation in a conversation with one or more prospective buyers with the aim of creating sales. Based on these definitions, personal selling is different from other promotional activities. By using personal selling, consumers will feel more concerned and easier to understand the products offered.

Hypothesis 3: Personal selling has a significant effect on the decision to use micro-business loans. The better the personal selling, the higher the interest in using micro-business loans (KUM).

Meaning: Based on these definitions, personal selling is different from other promotional activities. By using personal selling, consumers will feel more concerned and easier to understand the products offered. Therefore, if the higher personal selling for KUM submission by getting a good credit use decision, it will lead to comfort and satisfaction in the use of KUM customers, it will have an impact on the emergence of the customer's desire to make decisions in the use of Micro Business Loans.

The Influence of Accessibility, Personal Sales and Interest in the Decision of Use of Micro Business Credits (KUM) and Customer Loyalty (Study on Customer of BANK MANDIRI Sepanjang Kota Sidoarjo)

\section{Sonny Brilliant Candra Negara}


Hypothesis 4: Personal selling has a significant effect on customer loyalty, the higher the accessibility provided by a bank, the higher the customer loyalty.

Meaning: According to Kotler (2008) Personal selling is the most cost-effective tool at the stage of the advanced purchasing process, especially in building buyer's confidence and action preferences. Therefore, if the more appropriate personal selling for KUM submission by getting good customers, it will lead to comfort and satisfaction in the use of KUM customers, it will have an impact on the emergence of the customer's desire to make decisions and be loyal in using Micro Business Loans.

\section{Interest rate}

According to Mishkin (2008) the interest rate is the cost of the loan or the price paid for the loan fund (usually expressed as a percentage per year). Credit interest is the selling price that will be charged to the debtors. According to Banjarnahor (2006) obtained results that factor interest rates have a positive effect on credit demand.

Hypothesis 5: Interest rates have a significant effect on the decision to use micro-business loans. The more suitable the interest rate, the higher the interest in using micro-business loans (KUM)

Meaning: if the more appropriate interest rates for submitting KUM by getting good customers, it will lead to comfort and satisfaction in the customers using KUM, it will have an impact on the emergence of the customer's desire to make decisions in the use of Micro Business Loans.

Hypothesis 6: Interest rates have a significant effect on customer loyalty, the more appropriate the interest rate, the higher the customer loyalty.

Meaning: According to Tjiptono (1997) the main key to winning competition is to provide value and satisfaction to customers through the delivery of quality products and services and competitive prices. Therefore, if the more appropriate interest rates for filing KUM by obtaining good customers, it will lead to comfort and satisfaction in the use of KUM customers, it will have an impact on the emergence of the desire of customers to make decisions and be loyal in using Micro Business Loans.

\section{Decision on the Use of Micro-Business Credit}

According to Kotler (2002) purchasing decisions are actions of consumers to want to buy or not to the product. Of the various factors that influence consumers in purchasing a product or service, usually consumers always consider the quality, price and products already known by the public. Purchase decision from a prospective customer, to utilize the Micro Business Credit facility (KUM) at Bank Mandiri throughout the City. According to Tjiptono (2000) customer loyalty is a situation where consumers are positive towards the product or producer (service provider) and accompanied by a consistent repurchase pattern.

Hypothesis 7: The decision to use micro business credit has a significant effect on customer loyalty. The better the decision to use credit (KUM) the better the level of loyalty.

Meaning: If the customer is sure of the decision to use KUM credit, then the customer will always be loyal to us.

\section{Customer Loyalty}

Understanding loyalty According to Kotler, Armstrong (2006) is a satisfied customer who remains loyal and tells good things about the company and its products to others. Micro Business Credit (KUM) customers who are loyal to use Micro Business Credit (KUM) and Bank Mandiri products or services throughout the City.

The Influence of Accessibility, Personal Sales and Interest in the Decision of Use of Micro Business Credits (KUM) and Customer Loyalty (Study on Customer of BANK MANDIRI Sepanjang Kota Sidoarjo)

\section{Sonny Brilliant Candra Negara}




\section{METHODOLOGY}

The type of research used in this research is explanatory research. The location of the study was carried out at the MANDIRI BANK throughout the city of Sidoarjo. The variables studied were Accessibility variables, Personal selling, Interest Rate, Decision to Use Micro Business Loans, and Customer Loyalty. The number of samples in this study were 100 respondents from micro business credit users in the MANDIRI BANK throughout the city of Sidoarjo. Data collection techniques using a questionnaire. As well as data analysis methods using Partial Least Square (PLS) that uses SmartPLS 3 data processing software.

\section{Research Framework}

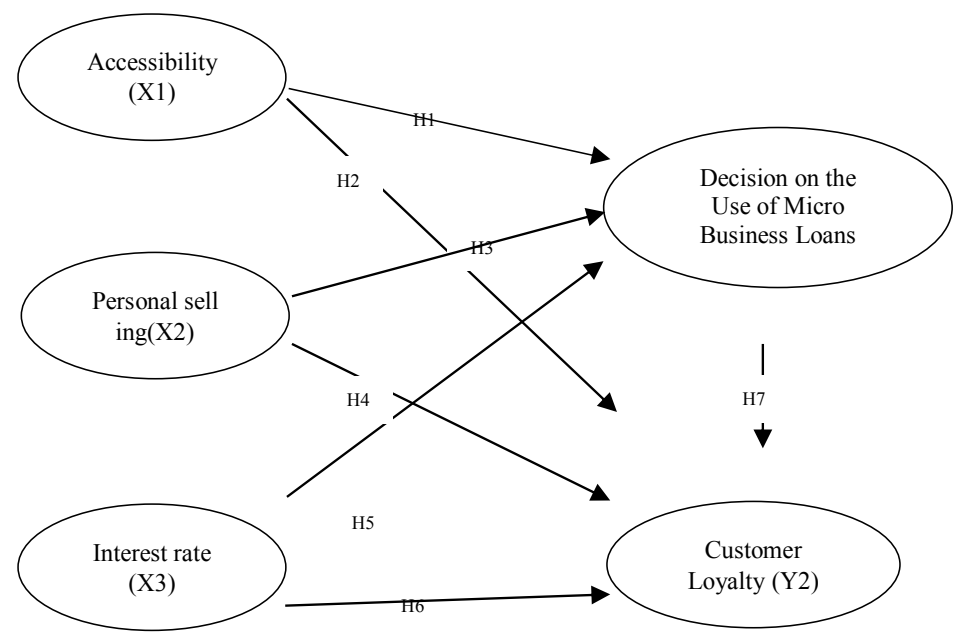

Figure $1:$ Research framework

\section{RESULTS AND DISCUSSION}

The R-Adjusted Decision variable for the Use of Micro Business Loans is 0.775 or $77.5 \%$. This result reflects that the variables of accessibility, personal selling and interest rates contribute $77.5 \%$ to the Decision on the Use of Micro Credit and the remaining $22.5 \%$ is by other factors, while for the customer loyalty, R-Adjusted variable is 0.833 or $83.3 \%$, this result shows that the variable contribution of accessibility, personal selling and interest rates contribute to influence the customer loyalty of $83.3 \%$ and the remaining $16,7 \%$ is influenced by other factors.

In testing the hypothesis, a data must meet a criterion, and the hypothesis is said to be accepted if the statistical value is greater than the t-statistic more than 1,656 and if the p-value is less than 0.05 and vice versa. The output of the SmartPLS is as follows:

The Influence of Accessibility, Personal Sales and Interest in the Decision of Use of Micro Business Credits (KUM) and Customer Loyalty (Study on Customer of BANK MANDIRI Sepanjang Kota Sidoarjo)

\section{Sonny Brilliant Candra Negara}


Tabel 1 : Path Coefficient

\begin{tabular}{|l|c|c|}
\hline \multicolumn{1}{|c|}{ Path Coefficient } & t-statistic & p-value \\
\hline Accessibility $\rightarrow$ Decision on the Use of Micro Business Loans & 2,029 & 0,022 \\
\hline Accessibility $\rightarrow$ Customer loyalty & 3,538 & 0,000 \\
\hline $\begin{array}{l}\text { Personal Selling } \rightarrow \text { Decision on the Use of Micro Business } \\
\text { Loans }\end{array}$ & 6,408 & 0,000 \\
\hline Personal Selling $\rightarrow$ Customer loyalty & 2,704 & 0,004 \\
\hline Interest rate $\rightarrow$ Decision on the Use of Micro Business Loans & 2,998 & 0,001 \\
\hline Interest rate $\rightarrow$ Customer loyalty & 2,976 & 0,002 \\
\hline $\begin{array}{l}\text { Decision on the Use of Micro Business Loans } \rightarrow \text { Customer } \\
\text { loyalty }\end{array}$ & 2,017 & 0,022 \\
\hline
\end{tabular}

Source, output SmartPLS 3.0, 2019

Hypothesis 1: Significant accessibility to the decision to use micro-business loans

Based on the results of the analysis using smartPLS, it can be concluded that the results of the accessibility hypothesis testing have a significant effect on the decision to use micro-business loans. the results of the first hypothesis test prove the t-statistic value $>1.656$ which is 2.029 and the p-value $<0.05$ is equal to 0.022 . This means that the higher the accessibility, the decision to use micro business loans also increases. The results of this study are in accordance with previous research, according to Baker (2002) accessibility may have different meanings from each customer, so this needs to be varied.

Conclusions can be drawn from the results of the research that accessibility has a variety of meanings, accessibility can affect the decision to use micro business loans as well as customer loyalty at Bank Mandiri throughout the city of Sidoarjo.

Hypothesis 2: Accessibility has a significant effect on customer loyalty

Based on the results of the analysis using smartPLS, it can be concluded that the results of the accessibility hypothesis testing have a significant effect on customer loyalty because the results of the second hypothesis test the $t$-statistic value $>1.656$ which is 3.538 and the $p$-value $<0.05$ is equal to 0.000 . This means that the higher the accessibility, the more customer loyalty increases. The results of this study are in accordance with previous research, according to Baker (2002) accessibility may have different meanings from each customer, so this needs to be varied.

Conclusions can be drawn from the results of the research that accessibility has a variety of meanings, accessibility can affect the decision to use micro business loans as well as customer loyalty at Bank Mandiri throughout the city of Sidoarjo.

Hypothesis 3: Personal selling has a significant effect on the decision to use micro business loans

Based on the results of the analysis using smartPLS, it can be concluded that the results of the accessibility hypothesis testing have a significant effect on the decision to use micro-business loans. the results of the third hypothesis test prove the t-statistic value $>1.656$ which is 6.408 and the p-value $<0.05$, which is equal to 0.000 . This means that the higher the personal selling, the decision to use micro business loans also increases. The results of this research are in accordance with previous research, according to Saladin (2007) which states that personal selling is an oral presentation in a conversation

The Influence of Accessibility, Personal Sales and Interest in the Decision of Use of Micro Business Credits (KUM) and Customer Loyalty (Study on Customer of BANK MANDIRI Sepanjang Kota Sidoarjo)

\section{Sonny Brilliant Candra Negara}


with one or more prospective buyers with the aim of creating sales. Based on these definitions, personal selling is different from other promotional activities. By using personal selling, consumers will feel more concerned and easier to understand the products offered

Therefore, if the higher personal selling for the submission of Micro Business Loans by getting a decision to use a good credit it will lead to comfort and satisfaction in the use of Micro Business Credit, it will have an impact on the emergence of a desire for customers to make decisions in the use of Micro Business Loans

Hypothesis 4 : Personal selling has a significant effect on customer loyalty.

Based on the results of the analysis using smartPLS, it can be concluded that the results of testing the personal selling hypothesis have a significant effect on customer loyalty. the results of the fourth hypothesis test prove the $\mathrm{t}$-statistic value $>1.656$ which is 2.704 and the $\mathrm{p}$-value $<0.05$ which is equal to 0.004 . This means that the higher the personal selling, the higher customer loyalty. The results of this research are in accordance with previous research, according to Kotler (2008) Personal selling is the most cost-effective tool at the stage of the advanced purchasing process, especially in building buyer confidence and action preferences.

The more suitable personal selling for the submission of Micro Business Loans by getting good customers, it will lead to comfort and satisfaction in the use of Micro Business Loans, it will have an impact on the emergence of the customer's desire to make decisions and be loyal in using Micro Business Loans.

Hypothesis 5: Interest rates have a significant effect on the decision to use micro business loans

Based on the results of the analysis using smartPLS, it can be concluded that the results of testing the interest rate hypothesis have a significant effect on the decision to use micro business loans. the results of the fifth hypothesis test prove the t-statistic value $>1.656$ which is 2.998 and the p-value $<0.05$, which is equal to 0.001 . This means that the more suitable the interest rate, the decision to use micro business loans also increases. Banjarnahor (2006) found that the interest rate factor has a positive effect on credit demand.

Therefore, if the more appropriate interest rates for filing KUM by obtaining good customers, it will lead to comfort and satisfaction in the use of KUM customers, it will have an impact on the emergence of the customer's desire to make decisions and be loyal in using Micro Business Loans.

Hypothesis 6 : Interest rates have a significant effect on customer loyalty

Based on the results of the analysis using smartPLS, it can be concluded that the results of testing the interest rate hypothesis have a significant effect on customer loyalty. the results of the sixth hypothesis prove the $\mathrm{t}$-statistic value $>1.656$ which is 2.976 and the $\mathrm{p}$-value $<0.05$, which is equal to 0.002 . This means that the more suitable the personal selling, the more customer loyalty increases. The results of this study are in accordance with the previous research. According to ) the main key to winning competition is to provide value and satisfaction to customers through the delivery of quality products and services and competitive prices.

The more suitable the interest rate for filing KUM by getting good customers, it will lead to comfort and satisfaction in the use of KUM customers, it will have an impact on the emergence of the desire of customers to make decisions in the use of Micro Business Loans

Hypothesis 7: The decision to use micro business credit has a significant effect on customer loyalty

Based on the results of the analysis using smartPLS, it can be concluded that the results of testing the interest rate hypothesis have a significant effect on customer loyalty. the results of the seventh

The Influence of Accessibility, Personal Sales and Interest in the Decision of Use of Micro Business Credits (KUM) and Customer Loyalty (Study on Customer of BANK MANDIRI Sepanjang Kota Sidoarjo)

\section{Sonny Brilliant Candra Negara}


hypothesis test prove the t-statistic value $>1.656$ which is 2.017 and the p-value $<0.05$ is equal to 0.022 . This means that the more appropriate customer loyalty, the loyalty of the decision to use micro business loans also increases. According to Tjiptono (2000) customer loyalty is a situation where consumers are positive towards the product or producer (service provider) and accompanied by a consistent repurchase pattern

Therefore, if the customer is convinced of the decision to use KUM credit, the customer will always be loyal to us. This shows that a significant positive impact on micro-business credit use decisions on customer loyalty is in accordance with the hypothesis proposed by the researcher.

\section{CONCLUSION}

\section{Conclusion}

The findings of this study indicate that the direct effect of variable accessibility, personal selling, interest rates has a significant influence on the decision to use micro-business loans and pnasabah loyalty in the MANDIRI BANK throughout the city of Sidoarjo. Respondents stated that they were quite amenable to accessibility, and the interest rates offered by banks and personal selling had the most dominant influence in shaping micro-credit use decisions and customer loyalty.

The practical implications of the results of this study suggest companies to prepare employees for good sales performance not only in terms of interpersonal skills, work experience, work training and work skills but also abilities and other skills that support the sales process to maintain customer loyalty. well

\section{REFERENCES}

Baker 2002. Marketing in Transition: Scarcity, Globalism, \& Sustainability:Proceedings Of The 2009 Wolrd Maketing Congress. DOI.10.1007./978-3-319-18687-0

Banjarnahor 2006. Mekanisme Suku Bunga SBI Sebagai Sasaran Operasional Kebijakan Moneter dan Variabel Makroekonomi Indonesia: 1990.1-2007.4. Buletin Ekonomi Moneter dan Perbankan, Juli 2008

Black 1981. Model Perencanaan Vefetasi Hutan Kota. Penerbit ANDI (anggota IKAPI), Yogyakarta.

Kotler \& Armstrong (2006). Prinsip-prinsip Pemasaran, Edisi XII, jilid 2, Erlangga, Jakarta.

Kotler 2002. Strategi Promosi yang Kreatif dan Analisis Kasus Integrated Marketing communication. Penerbit PT Gramedia Pustaka Utama. Jakarta

Kotler 2008. Prinsip - Prinsip Pemasan.Edisi 12 .Jilid 1. Jakarta : Erlangga

Mishkin, 2008. World Economic Outlook, April 2008: Housing and the Business Cycle. Penebit IMF Multimedia Services Fund. USA

Saladin 2007. Intisari Pemasaran dan Unsur - Unsur Pemasaran. Bandung : Penerbit Linda Karya. Yogyakarta

Tjiptono 1997. Strategi Pemasaran, Edisi Kedua, Penerbit Andi-Offset, Yogyakarta.

Tjiptono 2000. Komunikasi Pemasaran melalui Desain Visual, Hal 8., Penerbit Deepublish (Grup Penerbit CV.Budi Utama). Yogyakarta

The Influence of Accessibility, Personal Sales and Interest in the Decision of Use of Micro Business Credits (KUM) and Customer Loyalty (Study on Customer of BANK MANDIRI Sepanjang Kota Sidoarjo)

\section{Sonny Brilliant Candra Negara}

